\title{
Performance of Semi-Aerobic Solid Waste Bioreactor in relation to Decomposition Process and Biogas Production
}

\author{
Wiharyanto Oktiawan $^{1, *}$, Endro Sutrisno ${ }^{1}$, and Mochtar Hadiwidodo ${ }^{1}$, \\ ${ }^{1}$ Department of Environmental Engineering, Faculty of Engineering, Diponegoro University, Semarang - Indonesia
}

\begin{abstract}
Solid waste which is sent to Jatibarang landfill in Semarang City can reach up to $4000 \mathrm{~m}^{3} /$ day. The composition of solid waste consists of $61.95 \%$ of organic waste and $38.05 \%$ of inorganic waste. The environmental impacts of solid waste can be reduced using bioreactor methods which being able to accelerate the solid waste decomposition. Large amount of solid waste which is sent to Jatibarang landfill certainly has great potential to environment pollution. Therefore, a technology such as landfill bioreactor is needed to speed up the decomposition process of organic solid waste. Landfill bioreactors are characterized using a range of technologies in order to create an suitable environment for degradation processes. In this study four bioreactors simulated landfills that consist of hybrid bioreactors and anaerobic control bioreactors. The result shows that hybrid bioreactor has increases the decomposition process of organic solid waste. The hybrid bioreactor also produce more methane in subsequent anaerobes.
\end{abstract}

Keywords: Solid waste; decomposition; bioreactor; landfill.

\section{Introduction}

Jatibarang landfill is a final waste processing site located in Semarang City. Jatibarang landfill began its operation in 1993 as one of the waste management facilities. Jatibarang landfill receives waste approximately 800 to 900 tons per day or $4000 \mathrm{~m}^{3} /$ day. The composition of waste that goes to Jatibarang landfill consists of food waste $(43 \%)$, garden waste $(9 \%)$, paper $(12 \%)$, wood $(4 \%)$, textile $(1 \%)$, nappies $(1 \%)$, plastic and other inert $(13 \%)$ and other waste $(7 \%)$.

The waste that goes to the landfill is then being sorted according to organic and inorganic classification. The inorganic waste is collected by scavengers to be recycled, while organic waste is dumped into the landfill. However, it is often found that unmanaged inorganic waste is getting mixed in the landfill. Organic waste in the landfill will decompose aerobically and anaerobically. Anaerobic decomposed waste produces byproducts namely leachate and biogas.

Leachate can be defined as liquid passing through pile of waste and carrying substances from the waste [1]. Leachate contains various solutes such as organic substances, inorganic salts, organic trace pollutant, and heavy metals [2]. Meanwhile, the age of landfill also affects the concentration of contaminants in leachate [3].

Biogas is a renewable energy that can replace fossil fuel. Biogas is rich in methane which can substitute natural gas [4]. Biogas contains 50-80\% methane, carbon dioxide $(25-50 \%)$, nitrogen $(0-10 \%)$, hydrogen $(0-1 \%)$, hydrogen sulfide $(0-3 \%)$ and oxygen $(0-2 \%)$ [5].
However, the influence of leachate quality which is represented by BOD and COD parameters on methane content in biogas has not been extensively studied. Therefore, this study aims to analyze the effect of BOD and COD values on leachate to biogas production of methane gas.

\section{Materials and methods}

This study was conducted by comparing the results data from the analysis of BOD and COD values with their effect on methane gas production generated on the reactors. The research was conducted at Integrated Solid Waste Treatment Plant (ISWTP) of Diponegoro University, Semarang. The location of Diponegoro University's Integrated Solid Waste Treatment Plant is in education area of Diponegoro University, as shown in Figure 1.

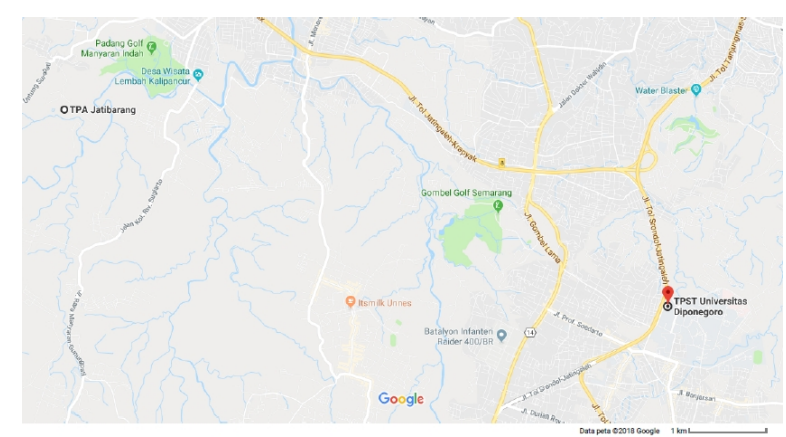

Fig.1. Location of study 
In this study, the value of $\mathrm{BOD}_{5}$ and $\mathrm{COD}$ concentrations is monitored during decomposition process of organic solid waste in all reactors. The generation of methane is also be observed by measuring the level of methane content in biogas. The test results of $\mathrm{BOD}_{5}$ and $\mathrm{COD}$ parameters present on the waste generation in the reactor would be compared to the biogas content in the reactor. From the data it could be seen whether the value of $\mathrm{BOD}_{5}$ and $\mathrm{COD}$ affected the amount of gas produced.

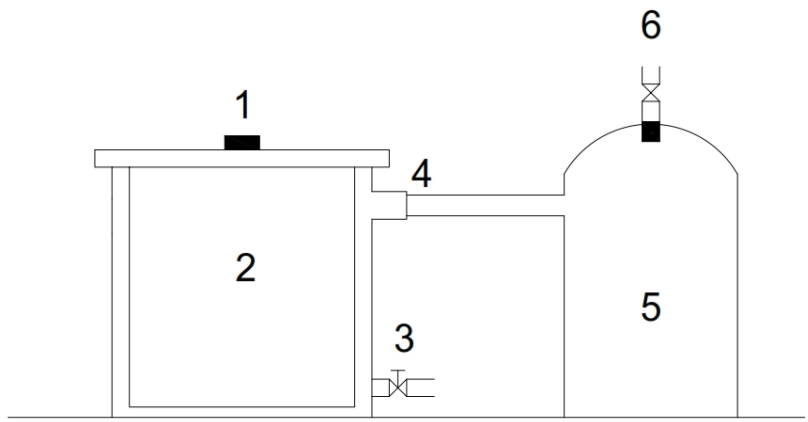

Legend:
1. Feed inlet
2. Digester
3. Sludge \& leachate outlet
4. Gas opening
5. Gas collector
6. Gas outlet

Fig.2. Diagram of Reactor

\section{Results and discussions}

\subsection{COD}

The COD value of reactors $\mathrm{R} 1, \mathrm{R} 2, \mathrm{R} 3$, and $\mathrm{R} 4$ had an downward trend from day 5 to day 20, then a COD decrease from day 20 to day 60 . The COD values of the four reactors at day 5 ranged from $5200 \mathrm{mg} \mathrm{O}_{2} / 1$ to 6600 $\mathrm{mg} \mathrm{O}_{2} / 1$ and at day 60 the COD value decreased to 4400 $\mathrm{mg} \mathrm{O}_{2} / 1$ to $5200 \mathrm{mg} \mathrm{O}_{2} / 1$. For example, based on figure 3 , there was a decrease trend in the value of COD in all reactors after day 20 . In the reactor $\mathrm{R} 1$, the $\mathrm{COD}$ value decreased from day 20 until day 60 , from $7230 \mathrm{mg} \mathrm{O} / 1$ to $5200 \mathrm{mg} \mathrm{O} / 1$. This indicates that young age landfills have a higher COD value than a long established landfill.

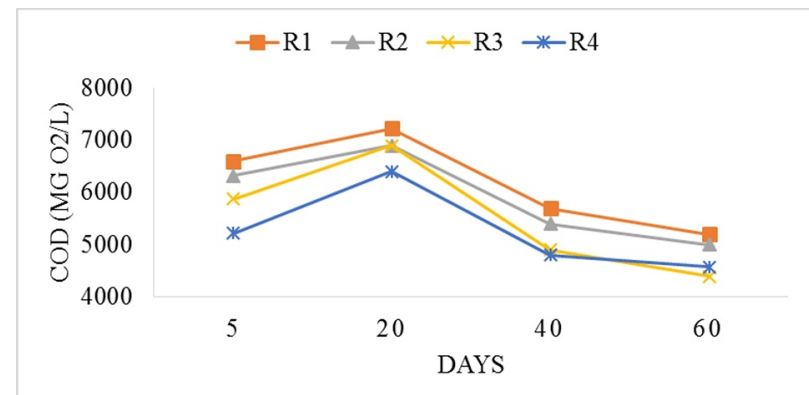

Fig.3. COD value
The COD value is affected by the occurrence of biological activity. The process of decomposition of organic materials by microorganisms produces biogas that contains methane gas and carbon dioxide. High COD concentration indicates that the anaerobic decomposition occurs at the first stage. At this stage the complex organic compounds are converted into watersoluble organic acids. Whereas low COD concentration indicates that the decomposition process takes place at the second level. The decomposition process will continue until a stable COD concentration is achieved [6].

\subsection{BOD}

According to figure $4, \mathrm{BOD}_{5}$ values of all reactors tend to increase along with the increase of composting time. The initial concentration of $\mathrm{BOD}_{5}$ value of $\mathrm{R} 2$ and $\mathrm{R} 4$ reactor have the same value of $70 \mathrm{mg} \mathrm{O} / 1$ while concentration in R1 and $\mathrm{R} 3$ are is $65 \mathrm{mg} \mathrm{O} / 1$ and $60 \mathrm{mg}$ $\mathrm{O}_{2} / 1$ respectively. At the day 40 , the COD concentration of $\mathrm{R} 1$ drops back to $65 \mathrm{mg} \mathrm{O}_{2} / 1$ before increase to $80 \mathrm{mg}$ $\mathrm{O}_{2} / 1$ at day 60 . The highest concentration at day 60 of $\mathrm{BOD}_{5}$ is shown by reactor R3 with the value of $108 \mathrm{mg}$ $\mathrm{O}_{2} /$ l. In reactor $\mathrm{R} 4$, the increment of $\mathrm{BOD}_{5}$ concentration is relatively constant, starting from $70 \mathrm{mg} \mathrm{O}_{2} / 1$ in day 5 and gradually increases to $95 \mathrm{mg} \mathrm{O}_{2} / 1$ in day 60 .

Increasing $\mathrm{BOD}_{5}$ concentration was influenced by high organic and moisture content causing biological activity to increase. High $\mathrm{BOD}_{5}$ and $\mathrm{COD}$ values were present along with Total Fatty Acid (TFA) which indicated the degradation occurring was low [7]. In this study the total of $\mathrm{BOD}_{5}$ decrease reached $80 \%$.

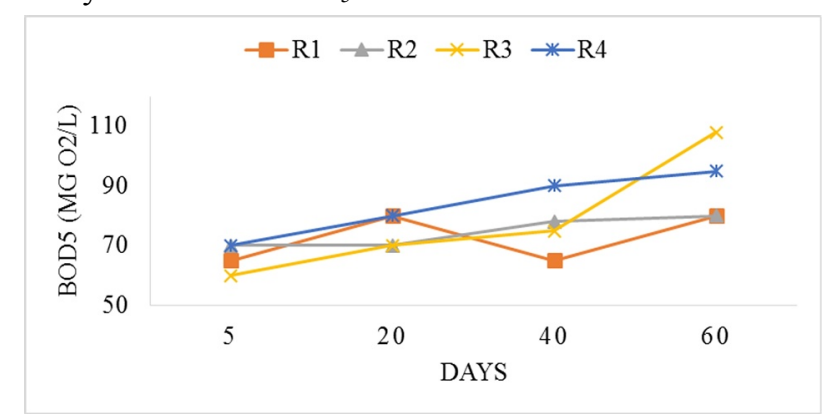

Fig.4. BOD value

The percentage of $\mathrm{CH}_{4}$ on $\mathrm{R} 1, \mathrm{R} 2, \mathrm{R} 3$ and $\mathrm{R} 4$ reactors fluctuated with increasing decomposition time. The percentage of $\mathrm{CH}_{4}$ in the four reactors ranged from $31.2 \%$ to $55.37 \%$. The percentage of $\mathrm{CH}_{4}$ in $\mathrm{R} 1$ had a tendency to increase with decomposition time, from $31.2 \%$ in September increasing to $36.88 \%$ in November. The percentage of $\mathrm{CH}_{4}$ in $\mathrm{R} 2$ tended to increase from September to October, but the $\mathrm{CH}_{4}$ percentage decreased in November. The percentage of $\mathrm{CH}_{4}$ in $\mathrm{R} 3$ tended to decrease from September to October and then increased in November. While the percentage of $\mathrm{CH}_{4}$ in $\mathrm{R} 4$ in September, October, and November tended to have the same value of $48 \%$. 


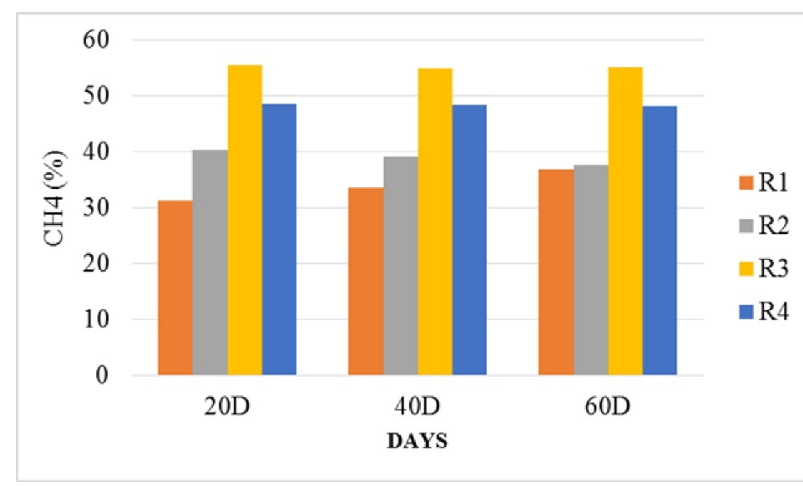

Fig.5. $\mathrm{CH}_{4}$ value

\section{Conclusion}

Leachate characteristics resulting from the decomposition process had $\mathrm{BOD}_{5}$ values ranging from $60-110 \mathrm{mg} \mathrm{O} / \mathrm{l}$, COD values ranging from 4400 to 6600 $\mathrm{mg} \mathrm{O}_{2} / \mathrm{l}$. The longer the decomposition time of the waste, BOD levels tend to increase along with the increase in volume and production of leachate. However, the opposite happened for COD parameter. The value of COD decreased as the rate of waste decomposition increased. Meanwhile, the biogas produced in the reactor contained methane of $31.2-54.99 \%$ and shows an increase trend.

This research was financially supported through Research of Development and Application (RPP) 2018 from Diponegoro University, Indonesia.

\section{References}

1. S.M. Raghab, A.M. Abd El Meguid, H.A. Hegazi, HBRC J. (2013)

2. C.M. Moody, T.G. Townsend, Waste Manage. (2017).

3. S. Renou, J.G. Givaudan, S. Poulain, F. Dirassouyan, P. Moulin, J Hazard Mater. (2008).

4. P. Weiland, App Microbiol Biotechnol. (2010).

5. C. Mao, Y. Feng, X. Wang, G. Ren, Renew Sust Energy Rev, 45 (2015).

6. M.A. Budihardjo, E. Sutrisno, M. Fatimah, MATEC Web Conf. 159 (2018)

7. F. Fantozzi, C. Buratti, Bioresource Technology 102 (2011) 